\title{
HUBUNGAN FAKTOR KARAKTERISTIK INDIVIDU DAN KONDISI PEKERJAAN TERHADAP STRES KERJA PADA PERAWAT GIGI
}

\author{
Rian Rosihan Ansori*, Tri Martiana** \\ *,**Departemen Keselamatan dan Kesehatan Kerja, Fakultas Kesehata Masyarakat \\ Universitas Airlangga, Surabaya, Jawa Timur, Indonesia \\ Alamat Korespondensi: \\ Rian Rosihan Ansori \\ Email: rianrosihanansori@gmail.com
}

\begin{abstract}
Job stress is an adaptive response and feedback adjustment in a condition individuals and the environment. Dental nurses face a variety of things in their duties that can cause stress, both physically and mentally. The objectives of this research are conducted to determine whether there is a correlation between individual characteristics and conditions of employment factors to the occurrence of occupational stress. The research was conducted with cross sectional design. By filling the questionnaire conducted to 22 dental nurses. Amount of samples used total population. The independent variables were the individual characteristics (age, sex, and years of marriage) and factor conditions of employment (demand, support, ties up job roles). The result of the research showed that there was a strong relationship between job stress with sex, there was a strong relationship between job stress with the demands of work, there was enough relationship between job stress with age, tenure, support employment, labor relations and the role of work on dental nurses. The suggestion of results this study recommends that dental nurses need off work and do refreshing, providing training to dental nurses in improving the capability and skills. Relating to the implementation of the tasks, it'd better to conduct joint training among employees. They are aimed for the sake of increasing solidarity and friendshipness among colleagues. Giving rewards to employees are also recommended for the best achievement at work.
\end{abstract}

Keywords: job stress, work period, work demands

\begin{abstract}
ABSTRAK
Perawat gigi dalam menjalankan tugasnya menghadapi berbagai hal yang dapat menyebabkan stres baik secara fisik dan mental. Penelitian ini dilakukan untuk mengetahui ada tidaknya hubungan antara faktor karakteristik individu dan faktor kondisi pekerjaan terhadap timbulnya stres kerja. Penelitian dilaksanakan dengan rancangan cross sectional. Pengisian kuesioner dilakukan oleh 22 orang perawat gigi. Jumlah sampel menggunakan total populasi. Variabel bebas penelitian ini adalah karakteristik individu (usia, jenis kelamin, masa kerja, pernikahan) dan faktor kondisi pekerjaan (tuntutan, dukungan, hubungan hingga peran kerja). Hasil uji statistik korelasi Spearman menunjukkan bahwa terdapat hubungan yang kuat antara stres kerja dengan jenis kelamin, terdapat hubungan yang kuat antara stres kerja dengan tuntutan kerja, terdapat hubungan yang cukup antara stres kerja dengan usia, masa kerja, dukungan kerja, hubungan kerja dan peran kerja pada perawat gigi. Saran penelitian menganjurkan kepada perawat gigi yang mengalami stres kerja untuk cuti kerja, memberi pelatihan kepada perawat gigi dalam meningkatkan kemampuan dan keterampilan dalam hal yang berkaitan dengan pelaksanaan tugas, mengadakan pelatihan bersama antar pegawai yang sifatnya bertujuan meningkatkan rasa solidaritas dan keakraban antar sesama rekan kerja, memberikan reward kepada pegawai yang memiliki prestasi kerja.
\end{abstract}

Kata kunci: stres kerja, masa kerja, tuntutan kerja 


\section{PENDAHULUAN}

Upaya kesehatan kerja sudah seharusnya diselenggarakan di semua tempat kerja, khususnya tempat kerja yang mempunyai risiko bahaya kesehatan, mudah terjangkit penyakit atau mempunyai karyawan paling sedikit 10 orang yang sesuai dengan Undang-Undang Nomor 23 Tahun 1992 Pasal 23 tentang Kesehatan Kerja. Salah satu tempat kerja yang dimaksud adalah pelayanan kesehatan seperti puskesmas dengan tenaga kesehatan di dalamnya.

Tenaga kesehatan merupakan suatu pekerjaan yang memiliki risiko tinggi terhadap timbulnya stress. Stres merupakan rangsangan atau aksi dari tubuh manusia baik itu dari luar maupun dalam tubuh manusia di mana dapat menimbulkan dampak yang merugikan mulai dari menurunnya kesehatan sampai kepada dideritanya suatu penyakit. Stres akibat kerja juga merupakan suatu respons emosional dan fisik yang bersifat mengganggu atau merugikan, yang terjadi pada saat tuntutan tugas tidak sesuai dengan kapabilitas, sumber daya, atau keinginan pekerja (NIOSH, 1999).

Salah satu profesi tenaga kesehatan adalah tenaga keperawatan. yang mana menurut survey di Perancis dalam Frasser (1997) mengungkapkan bahwa persentase terjadinya stres sekitar $74 \%$ dialami oleh profesi keperawatan. Mereka mengeluh terhadap lingkungan kerjanya yang menuntut kekuatan fisik dan keterampilan. Selain itu, penelitian dari National Institute for Occupational Safety and Health (NIOSH) menetapkan keperawatan sebagai profesi yang berisiko sangat tinggi terhadap stress (Schultz dan Schultz, 1994). Stress dapat berdampak secara emosional meliputi cemas, depresi, tekanan fisik dan psikologis (Potter \& Perry, 2007). Dampak kognitif berakibat pada penurunan konsentrasi, peningkatan distraksi dan berkurangnya kapasitas memori jangka pendek. Dampak pada perilaku misalnya meningkatkan ketidakharmonisan kerja, mengganggu pola tidur dan mengurangi kualitas pekerjaan
(Eysenck, 2009). Stres kerja dipengaruhi beberapa faktor antara lain faktor kondisi pekerjaan meliputi tuntutan kerja, dukungan kerja, peran kerja (Tarwaka dkk, 2004).

Menurut Keputusan Menteri Kesehatan Nomor 1035/Menkes/SK/IX/1998 Perawat gigi merupakan salah satu dari rumpun keperawatan. Perawat gigi dalam menjalankan tugasnya menghadapi berbagai hal yang dapat menyebabkan stress seperti menghadapi pasien yang sedang sakit, keharusan untuk bersikap baik kepada orang yang mungkin tidak disukai, berbicara dengan kerabat pasien dan bertatap muka langsung dengan orang lain, risiko yang sangat besar dari keputusan yang salah, risiko penularan penyakit akibat kerja (Grainger,1999).

Hasil wawancara dengan beberapa perawat gigi yang bekerja di wilayah kerja Puskesmas Kabupaten Bangkalan, diasumsikan bahwa banyak perawat yang indikasi mengalami stres kerja. Hal ini terlihat dari banyaknya keluhan nyeri otot dan nyeri punggung, jantung berdebar, mudah marah, sulit konsentrasi, perasaan lelah serta nafsu makan menurun. Hal ini merupakan gejala-gejala adanya stres kerja (Anoraga, 2001).

Sesuai dengan profesinya perawat gigi di wilayah kerja Puskesmas Kabupaten Bangkalan yang mempunyai karakteristik individu beragam mulai dari segi umur, massa kerja, status pernikahan dan jenis kelamin dan dituntut untuk memiliki kemampuan dan keterampilan dalam upaya membantu pasien mengatasi masalahnya terutama pada masalah gigi dan mulut. Tuntutan tersebut dapat menyebabkan terjadinya stres. Selain itu, perawat gigi dalam menjalankan profesinya sering memiliki beban kerja yang berlebih ketika dihadapkan pekerjaan di luar kompetensi yang harus mereka kerjakan.

Stres yang terjadi pada perawat gigi apabila tidak ditangani dengan tepat dapat menimbulkan suatu penyakit fisik, psikologi dan dapat memengaruhi kinerja perawat terhadap mutu pelayanan kesehatan di tempat 
kerja. Kondisi ini baik secara langsung maupun tidak langsung dapat berpengaruh terhadap pandangan pasien maupun keluarga terhadap pelayan di puskesmas yang dapat merugikan puskesmas itu sendiri. Oleh karena itu peneliti tertarik untuk meneliti hubungan faktor karakteristik individu dan faktor kondisi pekerjaan terhadap stres kerja pada perawat gigi di wilayah kerja Puskesmas se-Kabupaten Bangkalan.

\section{METODE PENELITIAN}

Penelitian ini merupakan penelitian observasional yaitu dilakukan dengan cara mengamati objek penelitian tanpa memberikan perlakuan. Berdasarkan waktu pelaksanaannya, penelitian ini merupakan penelitian cross sectional karena data tentang variabelnya diperoleh pada satu waktu, sedangkan berdasarkan sistem analisisnya termasuk penelitian analitik, dengan menggunakan uji korelasi spearman karena ingin mengetahui kuat hubungan antar variabel dengan kategori $0=$ tidak ada korelasi antara dua variabel,

$>0-0,25$ : korelasi sangat lemah, > $0,25-0,5$ : korelasi cukup, $>0,5-0,75$ : korelasi kuat, $>0,75-0,99$ : korelasi sangat kuat dan 1 : korelasi sempurna

Populasi penelitian ini yaitu semua perawat gigi di puskesmas se-Kabupaten Bangkalan yang berjumlah 22 orang perawat gigi, sedangkan pengambilan sampel penelitian adalah teknik total populasi. Penelitian ini dilaksanakan di puskesmas seKabupaten Bangkalan di mana pemilihan tempat ini dikarenakan belum pernah dijadikan lokasi penelitian sejenis dan berdasarkan hasil survey didapatkan bahwa terdapat tenaga perawat gigi yang mengalami stres kerja karena factor kondisi pekerjaan. Penelitian ini dilakukan pada bulan Oktober 2016 sampai Januari 2017.

Variabel independen pada penelitian ini yaitu factor karakteristik individu (usia, jenis kelamin, masa kerja). Usia adalah Jumlah tahun yang dihitung mulai dari responden lahir hingga saat penelitian berlangsung.
Skala data yang digunakan adalah ordinal, dengan 4 kategori 20-24 tahun, 25-29 tahun, 30-34 tahun dan $>34$ tahun. Jenis kelamin adalah jenis kelamin biologis responden menurut KTP. Skala yang digunakan adalah skala nominal, dengan kategori laki-laki dan perempuan. Masa kerja adalah jumlah tahun responden terhitung sejak tanggal mulai bekerja sebagai perawat gigi di instansi tempat bekerja sampai dengan penelitian ini dilaksanakan dalam hitungan tahun. Skala data ordinal dengan mengklasifikasikan masa kerja $<5$ tahun, 5-10 tahun dan $>10$ tahun. faktor kondisi pekerjaan (tuntutan kerja, dukungan kerja, hubungan kerja, peran kerja). tuntutan kerja adalah Pekerjaan yang harus sudah terselesaikan pada waktu yang telah ditentukan. Skala data yang digunakan adalah skala data ordinal dengan mengklasifikasikan tuntutan kerja rendah 9-21, cukup tinggi 22-23, sangat tinggi 34-35. Dukungan kerja adalah dorongan yang diperoleh dari semua lini untuk keberhasilan pekerjaan. Skala data yang digunakan adalah skala ordinal dengan klasifikasi dukungan kerja Lemah 5-11 cukup kuat 12-18, sangat kuat 19-25. Hubungan kerja adalah Interaksi yang dilakukan dalam melaksanakan pekerjaan dengan skala data yang digunakan adalah skala data ordinal dengan klasifikasi hubungan kerja kurang baik 5-11, cukup baik 12-18, sangat baik 19-25. Peran kerja adalah keterlibatan dan keikutsertaan dalam pekerjaan, dengan skala data yang digunakan adalah skala data ordinal dengan klasifikasi kurang aktif 5-11, cukup aktif 12-18, sangat aktif $19-25$, untuk variabel dependen penelitian ini yaitu stres kerja. Stres kerja adalah respons emosional dan fisik yang bersifat mengganggu atau merugikan yang terjadi pada saat tuntutan tugas tidak sesuai dengan kapabilitas, sumber daya, atau keinginan pekerja dengan skala data yang digunakan adalah skala data ordinal dengan klasifikasi stress ringan 15-18, stress sedang 19-25, stres berat 26-33.

Sumber data yang digunakan adalah data primer dengan cara wawancara 
menggunakan kuesioner untuk mengetahui factor kondisi pekerjaan dan stress kerja.

Alat ukur yang digunakan dalam penelitian ini adalah Depression Anxiety Stress Scale yang dikembangkan oleh lovibond dan Lovibond (1995) merupakan alat ukur tingkat depresi, kecemasan, dan stres seseorang. Pertanyaan yang harus dijawab oleh subjek penelitian terdiri dari 15 item pertanyaan. Skala depresi menilai dysphoria, purus asa, devaluasi hidup, sikap meremehkan diri, kurangnya minat, anhedinia, inersia. Skor yang digunakan menggunakan 4 kriteria yang dialami responden selama satu minggu terakhir. dari nilai 0 yang berarti tidak sesuai atau tidak pernah sampai 3 yang artinya sangat sesuai atau sering sekali. Kemudian skor dijumlahkan untuk mendapat total tingkat stress. Instrumen Faktor karakteristik individu menggunakan kuesioner yang berisikan pertanyaan mengenai umur, masa kerja dan jenis kelamin. Instrumen Faktor kondisi pekerjaan yaitu kuesioner yang terdiri atas 25 pertanyaan, di mana dari 25 pertanyaan itu terdiri dari 9 pertanyaan untuk kuesioner tuntutan kerja dengan skoring 1 yang berarti tidak pernah sampai 5 yang berarti selalu. Untuk kuesioner dukungan kerja terdiri dari 4 pertanyaan dengan skoring 1 untuk tidak pernah 5 untuk selalu. Untuk kuesioner hubungan kerja ada 3 pertanyaan dengan skoring tidak pernah 1 sampai selalu 5, dan 2 pertanyaan lagi dengan skoring sangat tidak setuju 1 dan sangat setuju 5, dengan kategori kurang baik 5-11, cukup baik 12-18 dan sangat baik 19-25. Kuisioner peran kerja ada 5 pertanyaan dengan skoring 1 untuk tidak pernah sampai 5 untuk selalu, dengan pengkategorian: kurang aktif 5-11, cukup aktif 12-18 dan sangat baik 19-25.

\section{HASIL}

\section{Usia}

Usia adalah Jumlah tahun yang dihitung mulai dari responden lahir hingga saat penelitian berlangsung. Hasil dari total 22 responden perawat gigi pada penelitian ini menunjukkan bahwa dari 4 kategori usia perawat gigi, ternyata yang mengalami stres kerja terbanyak adalah perawat gigi yang mempunyai usia lebih dari 34 tahun yaitu sebanyak $7(58,3 \%)$ orang mengalami stres kerja sedang. Hasil dari uji statistik tersebut diketahui bahwa nilai $r$ sebesar $-0,36$ yang berarti ada korelasi antara variable usia terhadap stress kerja perawat gigi kuat dan searah.

Tabel 1. Hubungan Usia dengan Stres Kerja Perawat Gigi Puskesmas seKabupaten Bangkalan

\begin{tabular}{|c|c|c|c|c|c|c|c|c|}
\hline \multirow{3}{*}{ Umur } & \multicolumn{6}{|c|}{ Kategori Stres Kerja } & \multirow{2}{*}{\multicolumn{2}{|c|}{ Total }} \\
\hline & \multicolumn{2}{|c|}{ Ringan } & \multicolumn{2}{|c|}{ Sedang } & \multicolumn{2}{|c|}{ Berat } & & \\
\hline & $\mathbf{n}$ & $\%$ & n & $\%$ & n & $\%$ & $\mathbf{N}$ & $\%$ \\
\hline $20-24$ & 1 & 33,3 & 1 & 33,3 & 1 & 33,3 & 3 & 100,0 \\
\hline $25-29$ & 0 & 0,0 & 4 & 100,0 & 0 & 0,0 & 4 & 100,0 \\
\hline $30-34$ & 1 & 33,3 & 2 & 66,7 & 0 & 0,0 & 3 & 100,0 \\
\hline$>34$ & 5 & 41,7 & 7 & 58,3 & 0 & 0,0 & 12 & 100,0 \\
\hline Total & & & & & & & 22 & 100,0 \\
\hline
\end{tabular}

\section{Jenis Kelamin}

Jenis kelamin merupakan jenis kelamin biologis responden. Hasil dari total 22 responden perawat gigi pada penelitian ini menunjukkan bahwa perempuan merupakan responden yang paling banyak mengalami stres kerja yakni sebabnya $14(73,3 \%)$ orang dalam kategori stres sedang. Hasil dari uji statistik tersebut diketahui bahwa nilai $r$ sebesar 0,557 yang berarti ada korelasi antara variable jenis kelamin terhadap stress kerja perawat gigi kuat dan searah.

Tabel 2. Hubungan Jenis Kelamin Kerja dengan Stres Kerja Perawat Gigi Puskesmas se-Kabupaten Bangkalan

\begin{tabular}{lrrrrrrrrr}
\hline \multirow{2}{*}{$\begin{array}{c}\text { Jenis } \\
\text { Kelamin }\end{array}$} & \multicolumn{4}{c}{ Kategori Stres Kerja } & \multicolumn{1}{c}{ Total } \\
\cline { 2 - 7 } & Ringan & \multicolumn{1}{c}{ Sedang } & \multicolumn{1}{c}{ Berat } & & \\
\cline { 2 - 8 } & $\mathbf{n}$ & $\mathbf{\%}$ & $\mathbf{n}$ & $\mathbf{\%}$ & $\mathbf{n}$ & $\mathbf{\%}$ & $\mathbf{N}$ & $\mathbf{\%}$ \\
\hline Laki laki & 3 & 100,0 & 0 & 0,0 & 0 & 0,0 & 3 & 100,0 \\
Perempuan & 4 & 21,1 & 14 & 73,7 & 1 & 4,5 & 19 & 100,0 \\
\hline Total & & & & & & 22 & 100,0 \\
\hline
\end{tabular}




\section{Massa Kerja}

Massa kerja adalah Jumlah tahun responden terhitung sejak tanggal mulai bekerja sebagai pekerja di bagian pengepakan sampai dengan penelitian ini dilaksanakan dalam hitungan tahun. hasil dari total 22 responden perawat gigi pada penelitian ini penelitian diperoleh bahwa dari ketiga kategori masa kerja. Ternyata yang mengalami stres kerja terbanyak adalah kategori masa kerja 5-10 tahun yakni 7 $(100 \%)$ orang mengalami stres sedang. Hasil dari uji statistik tersebut diketahui bahwa nilai $\mathrm{r}$ sebesar $-0,467$ yang berarti ada korelasi antara variable masa kerja terhadap stres kerja perawat gigi cukup dan tidak searah

Tabel 3. Hubungan Masa Kerja dengan Stres Kerja Perawat Gigi Puskesmas se-Kabupaten Bangkalan

\begin{tabular}{lcrcccccc}
\hline \multirow{2}{*}{$\begin{array}{r}\text { Masa } \\
\text { Kerja }\end{array}$} & \multicolumn{4}{c}{ Kategori Stres Kerja } & \multirow{2}{*}{ Total } \\
\cline { 2 - 7 } & Ringan & \multicolumn{1}{c}{ Sedang } & \multicolumn{3}{c}{ Berat } & & \\
\cline { 2 - 8 } & $\mathbf{n}$ & $\mathbf{\%}$ & $\mathbf{n}$ & $\mathbf{\%}$ & $\mathbf{n}$ & $\mathbf{\%}$ & $\mathbf{n}$ & $\mathbf{\%}$ \\
\hline$<5$ Thn & 1 & 25,0 & 2 & 50,0 & 1 & 25,0 & 4 & 100,0 \\
$5-10 \mathrm{Thn}$ & 0 & 0,0 & 7 & 100,0 & 0 & 0,0 & 7 & 100,0 \\
$>10 \mathrm{Thn}$ & 6 & 54,5 & 5 & 45,5 & 0 & 0,0 & 11 & 100,0 \\
\hline Total & & & & & & & 22 & 100,0 \\
\hline
\end{tabular}

\section{Tuntutan Kerja}

Tuntutan kerja adalah Pekerjaan yang harus sudah terselesaikan pada waktu yang telah ditentukan. Tuntutan kerja juga dapat diartikan juga sebagai pshycological stressor. Hasil penelitian ini menunjukkan bahwa dari ketiga kategori tuntutan kerja, ternyata yang mengalami stress kerja terbanyak adalah $10(83,3 \%)$ perawat gigi yang mempunyai tuntutan kerja cukup tinggi dengan kategori stres kerja sedang. Hasil dari uji statistik tersebut diketahui bahwa nilai $\mathrm{r}$ sebesar 0,651yang berarti ada korelasi antara variable masa kerja terhadap stres kerja perawat gigi kuat dan searah.
Tabel 4. Hubungan Tuntutan Kerja dengan Stres Kerja Perawat Gigi Puskesmas se-Kabupaten Bangkalan

\begin{tabular}{lcccccccc}
\hline \multirow{2}{*}{$\begin{array}{c}\text { Tuntutan } \\
\text { Kerja }\end{array}$} & \multicolumn{4}{c}{ Kategori Stres Kerja } & \multirow{2}{*}{ Total } \\
\cline { 2 - 6 } & Ringan & Sedang & \multicolumn{1}{c}{ Berat } & & \\
\cline { 2 - 7 } & $\mathbf{n}$ & $\mathbf{\%}$ & $\mathbf{n}$ & $\mathbf{\%}$ & $\mathbf{n}$ & $\%$ & $\mathbf{n}$ & $\%$ \\
\hline $\begin{array}{l}\text { Sangat } \\
\text { Tinggi }\end{array}$ & 0 & 0,0 & 2 & 100,0 & 0 & 0,0 & 2 & 100,0 \\
$\begin{array}{l}\text { Cukup } \\
\text { Tinggi }\end{array}$ & 1 & 8,3 & 10 & 83,3 & 1 & 8,3 & 12 & 100,0 \\
Rendah & 6 & 75,0 & 2 & 25,0 & 0 & 0,0 & 8 & 100,0 \\
\hline Total & & & & & & & 22 & 100,0 \\
\hline
\end{tabular}

\section{Dukungan kerja}

Dukungan kerja adalah dorongan yang diperoleh perawat gigi dari semua lini untuk keberhasilan suatu pekerjaan. hasil penelitian ini menunjukkan bahwa dari ketiga kategori dukungan kerja ternyata yang mengalami stress terbanyak adalah kategori dukungan kerja lemah dengan kategori stress kerja sedang yaitu $8(100 \%)$ orang. Hasil dari uji statistik tersebut diketahui bahwa nilai $\mathrm{r}$ sebesar $-0,424$ yang berarti ada korelasi antara variable dukungan kerja terhadap stres kerja perawat gigi cukup dan tidak searah.

Tabel 5. Hubungan Dukungan Kerja dengan Stres Kerja Perawat Gigi Puskesmas se-Kabupaten Bangkalan

\begin{tabular}{|c|c|c|c|c|c|c|c|c|}
\hline \multirow{3}{*}{$\begin{array}{c}\text { Dukungan } \\
\text { Kerja }\end{array}$} & \multicolumn{6}{|c|}{ Kategori Stres Kerja } & \multirow{2}{*}{\multicolumn{2}{|c|}{ Total }} \\
\hline & \multicolumn{2}{|c|}{ Ringan } & \multicolumn{2}{|c|}{ Sedang } & \multicolumn{2}{|c|}{ Berat } & & \\
\hline & $\mathbf{n}$ & $\%$ & n & $\%$ & $\mathbf{n}$ & $\%$ & $\mathbf{n}$ & $\%$ \\
\hline Lemah & 0 & 0,0 & 8 & 100,0 & 0 & 0,0 & 8 & 100,0 \\
\hline $\begin{array}{l}\text { Cukup } \\
\text { Kuat }\end{array}$ & 7 & 50 & 6 & 42,9 & 1 & 7,1 & 14 & 100,0 \\
\hline $\begin{array}{l}\text { Sangat } \\
\text { Kuat }\end{array}$ & 0 & 0,0 & 0 & 0,0 & 0 & 0,0 & 0 & 100,0 \\
\hline Total & & & & & & & 22 & 100,0 \\
\hline
\end{tabular}

\section{Hubungan Kerja}

Hubungan kerja adalah Interaksi yang dilakukan dalam melaksanakan pekerjaan. Hasil penelitian ini menunjukkan bahwa 
dari tiga kategori hubungan kerja. Ternyata perawat gigi yang mengalami stres terbanyak adalah perawat gigi yang mempunyai hubungan kerja cukup baik yakni sebanyak $12(85,7 \%)$ orang mengalami stres kerja sedang. Hasil dari uji statistik tersebut diketahui bahwa nilai $r$ sebesar $-0,487$ yang berarti ada korelasi antara variable hubungan kerja terhadap stres kerja perawat gigi cukup dan tidak searah.

Tabel 6. Hubungan Kerja dengan Stres Kerja Perawat Gigi Puskesmas seKabupaten Bangkalan

\begin{tabular}{|c|c|c|c|c|c|c|c|c|}
\hline \multirow{3}{*}{$\begin{array}{c}\text { Hubungan } \\
\text { Kerja }\end{array}$} & \multicolumn{6}{|c|}{ Kategori Stres Kerja } & \multirow{2}{*}{\multicolumn{2}{|c|}{ Total }} \\
\hline & \multicolumn{2}{|c|}{ Ringan } & \multicolumn{2}{|c|}{ Sedang } & \multicolumn{2}{|c|}{ Berat } & & \\
\hline & $\mathbf{n}$ & $\%$ & $\mathbf{n}$ & $\%$ & $\mathbf{n}$ & $\%$ & $\mathbf{n}$ & $\%$ \\
\hline Lemah & 1 & 14,3 & 1 & 7,1 & 0 & 0 & 2 & 100,0 \\
\hline $\begin{array}{l}\text { Cukup } \\
\text { Kuat }\end{array}$ & 1 & 14,3 & 12 & 85,7 & 1 & 100 & 14 & 100,0 \\
\hline $\begin{array}{l}\text { Sangat } \\
\text { Kuat }\end{array}$ & 5 & 71,4 & 1 & 7,1 & 0 & 0 & 6 & 100,0 \\
\hline Total & & & & & & & 22 & 100,0 \\
\hline
\end{tabular}

\section{Peran Kerja}

Peran kerja adalah Keterlibatan dan keikutsertaan dalam pekerjaan. hasil penelitian ini menunjukkan bahwa dari tiga kategori peran kerja perawat gigi. Ternyata perawat gigi yang mengalami stres terbanyak adalah perawat gigi yang mempunyai peran kerja kurang aktif yakni sebanyak 7 (100\%) orang mengalami stres kerja sedang. Hasil dari uji statistik tersebut diketahui bahwa nilai $r$ sebesar $-0,498$ yang berarti ada korelasi antara variabel peran kerja terhadap stres kerja perawat gigi cukup dan tidak searah.

\section{PEMBAHASAN}

\section{Usia}

Usia berhubungan dengan bagaimana toleransi individu terhadap stres dan jenis stressor yang paling mengganggu. Pada seorang yang mempunyai usia dewasa biasanya mereka akan lebih mengontrol stres dibanding dengan usia kanak-kanak dan usia
Tabel 7. Hubungan Peran Kerja dengan Stres Kerja Perawat Gigi Puskesmas se-Kabupaten Bangkalan

\begin{tabular}{|c|c|c|c|c|c|c|c|c|}
\hline \multirow{3}{*}{$\begin{array}{l}\text { Peran } \\
\text { Kerja }\end{array}$} & \multicolumn{6}{|c|}{ Kategori Stres Kerja } & \multirow{2}{*}{\multicolumn{2}{|c|}{ Total }} \\
\hline & \multicolumn{2}{|c|}{ Ringan } & \multicolumn{2}{|c|}{ Sedang } & \multicolumn{2}{|c|}{ Berat } & & \\
\hline & $\mathbf{n}$ & $\%$ & n & $\%$ & $\mathbf{n}$ & $\%$ & $\mathbf{n}$ & $\%$ \\
\hline $\begin{array}{l}\text { Kurang } \\
\text { Aktif }\end{array}$ & 0 & 0,0 & 7 & 100,0 & 0 & 0,0 & 7 & 100,0 \\
\hline $\begin{array}{l}\text { Cukup } \\
\text { Aktif }\end{array}$ & 1 & 25,0 & 2 & 50,0 & 1 & 25,0 & 4 & 100,0 \\
\hline $\begin{array}{l}\text { Sangat } \\
\text { Aktif }\end{array}$ & 6 & 54,5 & 5 & 45,5 & 0 & 0,0 & 11 & 100,0 \\
\hline Total & & & & & & & 22 & 100,0 \\
\hline
\end{tabular}

lanjut. Dengan kata lain bias diartikan jika orang dewasa biasanya mempunyai toleransi terhadap stres yang lebih baik. Hasil analisis yang dilakukan bahwa karakteristik usia memiliki kuat hubungan cukup dan tidak searah terhadap timbulnya stres kerja. Hal ini berarti semakin rendah usia seseorang maka stres kerja semakin tinggi. Smet (1994), mengemukakan jika jenis stress yang berisiko dan berpotensial di bagi menjadi tiga tahap dalam kehidupan yakni pada masa kanak-kanak, masa remaja hingga masa dewasa, lain halnya penelitian yang dilakukan Prabowo (2009), yang mengemukakan bahwa tidak adanya hubungan antara umur seseorang dengan stres kerja. Faktor usia memang sulit dianalisis tersendiri karena masih banyak faktor dalam karakteristik individu lainnya yang ikut memengaruhi hubungan terhadap timbulnya stres kerja. Selain itu dengan bertambahnya umur pengalaman seseorang juga akan bertambah, pengetahuan lebih baik dan rasa tanggung jawab akan menjadi lebih tinggi, di mana hal ini akan menutupi kekurangan untuk mereka beradaptasi

Pada penelitian ini mayoritas perawat gigi berusia lebih dari 34 tahun yaitu sebanyak 12 orang. pada usia dewasa ini umumnya secara kognitif orang sudah mampu berfikir reflektif, yakni menggunakan pertimbangan yang hati-hati 
dan menerima keyakinan dan invormasi berdasarkan bukti yang mendukung untuk mencapai sebuah kesimpulan. Selain itu mereka juga sudah dapat dikatakan mencapai tahap pemikiran formal di mana mereka sudah memiliki kemampuan untuk menghadapi ketidakpastian, kontradiksi, ketidak konsistenan, ketidaksempurnaan serta dapat berkompromi dengan situasi tersebut.

\section{Jenis Kelamin}

Dari hasil statistik analisis yang dilakukan diperoleh bahwa Jenis kelamin memiliki korelasi hubungan cukup kuat terhadap timbulnya stres kerja. Hasil penelitian menunjukkan perempuan memiliki persentase lebih besar terhadap terjadinya stres dibandingkan laki-laki. Hal ini sesuai dengan teori Suma'mur (1994), yang mengemukakan bahwa antara laki-laki dan perempuan memiliki kemampuan fisik (otot) yang berbeda. Perempuan memiliki kecenderungan cepat lelah sehingga stres kerja lebih banyak dialami perempuan. Selain itu stres kerja juga dipengaruhi dengan adanya siklus haid pada wanita yang dapat memengaruhi kondisi emosionalnya. Emosi yang tidak stabil dapat memperberat stres kerja yang dialaminya.

Jenis kelamin dapat memengaruhi stres kerja pada penelitian ini dimungkinkan karena bagi perawat gigi yang berjenis kelamin perempuan yang memiliki kemampuan fisik lebih lemah dari pada laki-laki malah mereka dituntut bekerja lebih tinggi dari pada laki-laki. Perawat gigi perempuan selain menghadapi pekerjaan di tempat kerja mereka juga harus bekerja mulai dari pagi yaitu menyiapkan keperluan keluarga seperti memasak, mengurus anak hal ini juga mereka lakukan setelah mereka pulang dari bekerja, sehingga mereka cenderung mengalami kelelahan yang dapat memicu terjadinya stres.

\section{Masa Kerja}

Hasil analisis statistik yang dilakukan diperoleh jika masa kerja memiliki korelasi hubungan cukup terhadap timbulnya stres kerja dengan nilai tidak searah yang berarti semakin sedikit masa kerja maka stres kerja akan semakin tinggi. Hal ini sesuai dengan pendapat dengan pendapat yang dikemukakan oleh Koch dkk (1982), menunjukkan bahwa semakin lama masa kerja seseorang bekerja maka stres kerja yang dialami akan semakin ringan dikarenakan orang tersebut sudah berpengalaman dan cepat tanggap dalam menghadapi berbagai masalah-masalah pekerjaan. Selain itu Atkinson dan Jacqueline (1991), mengemukakan bahwa semakin sedikit massa kerja cenderung mengalami stress kerja.

Pada penelitian ini mayoritas perawat gigi memiliki masa kerja lebih dari 10 tahun di mana $6(54,5 \%)$ dari mereka termasuk golongan stres ringan. ringannya golongan stres kerja pada kelompok ini mungkin dikarenakan perawat gigi pada kelompok ini mempunyai kemampuan dalam mengatasi masalah, hal ini disebabkan oleh proses belajar maupun pengalaman-pengalaman sebelumnya dalam menghadapi kesulitan dalam bekerja. Hal ini berbeda dengan kelompok masa kerja di bawahnya di mana pada kelompok masa kerja 5-10 tahun semua responden mengalami stres kerja sedang dan untuk kelompok masa kerja kurang dari 5 tahun 2 orang mengalami stres kerja ringan bahkan satu orang memiliki stres kerja berat. Terjadinya stres sedang pada dua kelompok ini dimungkinkan karena masih kurangnya pengalaman mereka dalam menyelesaikan dan menghadapi permasalahan-permasalahan baru dalam pekerjaannya, sehingga perlu bagi mereka. untuk mengatasi masalah stres kerja akibat masa kerja mungkin dapat dilakukan dengan cara mengadakan rotasi kerja sehingga para pekerja tidak jenuh, mengadakan kegiatan refresing untuk menghilangkan kepenatan dalam bekerja.

\section{Tuntutan kerja}

Tuntutan tugas adalah pekerjaan yang harus sudah terselesaikan pada waktu yang telah ditentukan. Tuntutan kerja juga 
dapat didefinisikan sebagai sebuah tuntutan dalam pekerjaan yang akan menjadi sumber terjadinya kelelahan secara psikologis (pshycological stresor) (Peter, 2006). Dari hasil analisis statistik diperoleh jika tuntutan kerja memiliki korelasi hubungan cukup terhadap timbulnya stres kerja dengan nilai searah yang berarti semakin tinggi tuntutan kerja maka stres kerja juga semakin tinggi. hal ini sependapat dengan pendapat Cinamon dkk (2002), di mana stres kerja terjadi jika tuntutan kerja melebihi kemampuan atau kapasitas yang dimiliki seorang pekerja. Pendapat yang sama juga dikemukakan oleh Anatan dan Ellitan (2007), di mana pemberian beban kerja yang berlebihan terhadap pegawai dapat menimbulkan stres yang berkepanjangan, yakni keadaan yang tidak menyenangkan yang dihadapi seseorang baik secara fisik maupun mental.

Tuntutan kerja yang memengaruhi stres kerja pada perawat gigi dalam penelitian ini, mungkin dikarenakan besarnya tuntutan kerja yang dialami perawat gigi mulai dari harus melakukan pekerjaan di luar kompetensinya yang dikarenakan keterbatasan tenaga medis di tempat dia bekerja. Selain itu mereka juga dituntut harus bekerja dengan cepat dan teliti dengan kondisi peralatan dan sumber daya manusia yang terbatas. Jika para perawat gigi ini dibebani pekerjaan yang berlebih dan membutuhkan konsentrasi yang tinggi maka mereka akan tertekan fisiknya, mereka akan mulai kelelahan dan membuat tekanan secara psikologi sehingga mudah marah dan tersinggung. Hal seperti inilah yang akan menyebabkan timbulnya stres kerja. Seharusnya untuk mencegah hal ini terjadi peran dari pimpinan terkait sangat memengaruhi mulai dari pengadaan pelatihan untuk meningkatkan kemampuan pegawai dalam kompetensinya, penambahan pegawai yang sesuai untuk menempati tupoksi pekerjaan yang sebelumnya tidak ada, hingga diberlakukannya regulasi yang mendukung terkait pekerjaan di luar kompetensi perawat gigi agar ada payung hukum jika mereka bekerja di luar kompetensi.

\section{Dukungan Kerja}

Dukungan kerja adalah dorongan yang diperoleh perawat gigi dari semua lini untuk keberhasilan suatu pekerjaan. Hasil analisis statistik pada penelitian ini diperoleh bahwa ada hubungan antara dukungan kerja dengan stres kerja. Menurut Garmenzy dan Rutter (1983), bahwa dukungan yang positif mampu mengurangi kecemasan, di mana kecemasan merupakan salah satu faktor timbulnya stress kerja. Menurut Smet (1994), salah satu faktor yang memengaruhi stres kerja adalah dukungan sosial. Reaksi stres yang berbeda antara satu orang dengan orang lain ini disebabkan oleh beberapa faktor yang salah satunya adalah dukungan sosial.

Pada penelitian ini dukungan kerja merupakan faktor yang memiliki korelasi hubungan cukup terhadap timbulnya stres kerja dengan nilai tidak searah yang berarti semakin rendah dukungan kerja yang dirasakan maka stres kerja semakin tinggi. Kurangnya dukungan kerja pada perawat gigi mungkin karena para perawat gigi merasa dukungan yang diperoleh dari rekan kerja dan atasan tempat dia bekerja maupun lingkungan sekitar masih kurang, di mana sarana dan prasarana masih dianggap kurang, teman kerja dan atasan juga kurang membantu di saat perawat gigi memiliki kesulitan, sehingga dalam penelitian ini dukungan merupakan faktor yang berhubungan dengan stres kerja. Di mana apabila dukungan diberikan pada perawat gigi tersebut dirasa baik, perawat gigi akan merasa diperhatikan, tenang dan timbul rasa percaya diri dan kompeten, dan membuat mereka merasa bagian dari kelompok. Untuk itu dalam rangka menciptakan dukungan kerja yang baik dalam sebuah tempat kerja diperlukan adanya kegiatan bersama yang menciptakan suatu keakraban di antara mereka.

\section{Hubungan Kerja}

Hubungan kerja merupakan hubungan antara sesama pekerja dalam lingkungan kerja. Hasil analisis statistik pada penelitian 
ini diperoleh bahwa hubungan kerja merupakan faktor kondisi pekerjaan yang berhubungan terhadap timbulnya stres kerja. Menurut Beehr \& Newman dalam Ruslina (2004), mengemukakan bahwa hubungan interpersonal dengan rekan kerja, supervisor dan anak buah telah diidentifikasi sebagai sumber dari stres kerja. Selain itu penelitian ini juga sependapat dengan penelitian yang dilakukan oleh Pearse (1977), di mana dalam penelitiannya terhadap 5000 manager, ditemukan bahwa penyebab stres kerja yang utama dari manager tersebut adalah kurangnya dukungan dari supervisor, kinerja supervisor yang kurang efektif serta konflik yang terjadi dengan supervisor. Hubungan yang baik dengan rekan kerja tentu memberi banyak keuntungan bagi pekerja itu sendiri. Namun hubungan baik tentu perlu dibangun dan dijaga di dalam dunia kerja yang penuh dengan kesibukan.

Dari hasil penelitian ini hubungan kerja merupakan faktor yang memiliki korelasi hubungan cukup terhadap timbulnya stres kerja dengan nilai tidak searah yang berarti semakin rendah hubungan kerja yang dirasakan maka stres kerja semakin tinggi. Hubungan kerja yang kurang dikarenakan adanya kesenjangan pada perawat gigi yang mempunyai rekan kerja dokter gigi maupun sesama perawat di mana mereka merupakan anggota dari kepala ruangan poli sehingga mereka merasa bahwa kepala ruangan berada pada posisi atas dan harus selalu dihormati. Begitupun dengan para pekerja di poli lain. kesibukan masing-masing poli dalam menjalankan tugasnya juga dapat menimbulkan kesenjangan hubungan kerja. Maka dari itu perlu dilakukannya kegiatan yang dapat menimbulkan rasa kekompakan atau solidaritas antar sesama pekerja. Kegiatan ini dapat berupa pengadaan pelatihan bersama seperti outbound, atau partisipasi dalam lomba-lomba yang dapat meningkatkan keakraban dalam hubungan antar pekerja

\section{Peran Kerja}

Hasil analisis statistik dalam penelitian ini diketahui bahwa peran kerja merupakan kondisi dalam pekerjaan yang memiliki hubungan terhadap timbulnya stres kerja. Menurut Sutherland dan Cooper dalam Smet (1994), sumber stres kerja berasal langsung dari pekerjaan dan interaksi antara lingkungan sosial dengan pekerjaan, salah satunya konflik peran, peran di dalam kerja yang tidak jelas, tanggung jawab yang tidak jelas.

Dalam penelitian ini peran kerja merupakan kondisi pekerjaan yang berhubungan dengan timbulnya stres kerja pada perawat gigi. Stres kerja ini kemungkinan dikarenakan peran para perawat gigi belum berjalan dengan benar sehingga ada perawat gigi yang mengalami stres kerja karena peran yang kurang menyenangkan dalam bekerja mereka, tidak begitu paham tentang tugas dan tanggung jawab yang mereka kerjakan baik saat bekerja sendirian maupun sat berkolaborasi dengan rekan kerja baik dokter gigi maupun sesama perawat gigi. Banyak dari mereka melakukan peran kerja di luar lingkup yang seharusnya mereka kerjakan. Seharusnya organisasi dituntut pembagian tugas yang jelas, terstruktur, dan terbangun koordinasi, sinkronisasi dalam menjalankan peran dalam bekerja.

\section{SIMPULAN}

Berdasarkan hasil penelitian dapat disimpulkan bahwa ada kuat hubungan cukup antara faktor usia dengan timbulnya stres kerja, jenis kelamin memiliki kekuatan hubungan kuat sebagai faktor yang memengaruhi stres kerja, masa kerja mempunyai kuat hubungan cukup sebagai faktor yang memengaruhi stres kerja, tuntutan kerja mempunyai kuat hubungan cukup sebagai faktor yang memengaruhi stres kerja dukungan kerja mempunyai kuat hubungan cukup sebagai faktor yang 
memengaruhi stres kerja, Hubungan kerja mempunyai kuat hubungan cukup sebagai faktor yang memengaruhi stres kerja hubungan dan peran kerja mempunyai kuat hubungan cukup sebagai faktor yang memengaruhi stres kerja.

\section{DAFTAR PUSTAKA}

Anatan, L., Ellitan. 2007. Manajemen Sumber Daya Manusia dalam Bisnis Modern. Alfabeta. Bandung.

Anoraga, P. 2001. Psikologi Kerja. Jakarta: Rineka Cipta.

Atkinson, M., Jacqueline. 1991. Mengatasi Stres di Temoat Kerjaa. Jakarta: Binarupa Aksara.

Beehr, T.A., Newman, J.E. 1978. Job stress. Employee Health and Organization Effectiveness: A Facet Analisis Model and Literature Review. Personel Psichology.

Cinamon, R.C, Yisrael, R., Mina westman. 2002. Occupation Type and The WorkFamily Conflict: The Case of Teachers.

Eysenck, M.W. 2009. Fundamental of Psichology. New York: Psichology Stress.

Grainger, C. 1999. Stress survival guide:mengatasi stres bagi para dokter Alih bahasa: Manfred Himawan). Jakarta: Hiokrates. (Cet.aslin1994).

Garmenzy, M., Rutter, M. 1983. Stress Coping and Development In Children. New York: McGraw-Hill Publising Company.

Keputusan Menteri Kesehatan Nomor 1035/Menkes/SK/IX/1998 tentang Keperawatan Gigi.

Koch, J.L., Tung, R, Gmelch, W., Smet, B. 1982. Job Stress Among School Administrators: Factorial Demension and Differential Effects.,' Journal of Applied Psycho log1t. 67: 493-499.

Lovibon, S.H., Lovibon, P.F. 1995. Manual for the Depression Anxiety \& Stress Scales
(Second Edition). Psycology Foundation. http://www. Seren.me.uk.

NIOSH.2008. Exposure to Stress Occupational Hazard in Hospital. NIOSH.

Pearse, J.S. 1997. Distribution. nof Diadema savignyi and D. Setosum in the tropical pasific. In:mooi R, Telford M (eds) Echinoderms. AA Belkema, Roterdam, pp. 777-782.

Peter, J.P., Jerry C.O. 2006. Consumer Behavior and Marketing Strategy. $4^{\text {th }} \mathrm{ed}$. The McGraw-Hill Companies, Inc.

Potter., P. 2005. Buku ajar fundamental keperawatan: konsep, proses, praktik. (edisi 4), (Asih, Yasmim; Penerjemah). Jakarta: EGC.

Prabowo. 2009 Faktor yang Berhubungan dengan Kejadian Stres Kerja Pada Bagian Produksi Mebel PT. Chia Jian Indonesia Furniture di Wedelan Jepara Tahun 2009.http://www.depkes.go.id/ downloads/debu.pdf. [diakses tanggal 18 Februari 2011

Schultz, D., Schultz., P. 1994. Theories of Personality 5th Edition. California: Brooks/cole.

Smet, B. 1994. Psikologi Kerja. Jakarta: PT Gramedia Widiasarana.

Ruslina. 2004. Hubungan antara Konflik Peran Ganda dengan StresKerja Pada Wanita Bekerja. Skripsi. Universitas Muhammadiyah Surakarta.

Suma'mur, P.K. 1994. Higene Perusahaan dan Kesehatan Kerja. Haji Masagung, Jakarta.

Tarwaka., Bakri, S.H.A., Sudiajeng, L. 2004. Ergonomi untuk Keselamatan Kesehatan Kerja dan Produktivitas. Surakarta: PT UNIBA PRESS.

Undang-undang Republik Indonesia No.23 Tahun 1992 Tentang Kesehatan Kerja. 